\title{
Prokaryotic community structure and heterotrophic production in a river-influenced coastal arctic ecosystem
}

\author{
Marie-Ève Garneau ${ }^{1, *}$, Warwick F. Vincent ${ }^{1}$, Laura Alonso-Sáez ${ }^{2}$, Yves Gratton ${ }^{3}$, \\ Connie Lovejoy ${ }^{1,2}$ \\ ${ }^{1}$ Département de Biologie \& Centre d'études nordiques, Université Laval, Québec City, Québec G1K 7P4, Canada \\ ${ }^{2}$ Departament de Biología Marina i Oceanografia, Institut de Ciències del Mar-CMIMA, CSIC, Passeig Marítim de la \\ Barceloneta 39-47, 08009 Barcelona, Catalunya, Spain \\ ${ }^{3}$ Institut national de la recherche scientifique, Centre Eau, Terre et Environnement, 490 de la Couronne, Québec City, \\ Québec G1K 9A9, Canada
}

\begin{abstract}
Spatial patterns in prokaryotic biodiversity and production were assessed in the Mackenzie shelf region of the Beaufort Sea during open-water conditions. The sampling transect extended $350 \mathrm{~km}$ northwards, from upstream freshwater sites in the Mackenzie River to coastal and offshore sites, towards the edge of the perennial arctic ice pack. The analyses revealed strong gradients in community structure and prokaryotic cell concentrations, both of which correlated with salinity. Picocyanobacterial abundance was low $\left(10^{2}\right.$ to $10^{3}$ cells $\left.\mathrm{ml}^{-1}\right)$, particularly at the offshore stations that were least influenced by the river plume. Analysis by catalyzed reporter deposition for fluorescence in situ hybridization (CARD-FISH) showed that the dominant heterotrophic cell types were $\beta$-Proteobacteria at river sites, shifting to dominance by $\alpha$-Proteobacteria offshore. Cells in the Cytophaga-Flavobacter-Bacteroides and $\gamma$-Proteobacteria groups each contributed $<5 \%$ of total counts in the river, but $>10 \%$ of counts in the marine samples. Archaea were detected among the surface-water microbiota, contributing on average $1.3 \%$ of the total DAPI counts in marine samples, but $6.0 \%$ in turbid coastal and riverine waters. ${ }^{3} \mathrm{H}$-leucine uptake rates were significantly higher at 2 stations influenced by the river $\left(1.5 \mathrm{pmol}^{-1} \mathrm{~h}^{-1}\right)$ than at other marine stations or in the river itself $\left(\leq 0.5 \mathrm{pmol}^{-1} \mathrm{~h}^{-1}\right)$. Size-fractionation experiments at 2 coastal sites showed that $>65 \%$ of heterotrophic production was associated with particles $>3 \mu \mathrm{m}$. These results indicate the importance of particleattached prokaryotes, and imply a broad functional diversity of heterotrophic microbes that likely facilitates breakdown of the heterogeneous dissolved and particulate terrestrial materials discharged into arctic seas.
\end{abstract}

KEY WORDS: Prokaryote diversity · Archaea • Proteobacteria • Cytophaga-FlavobacterBacteroides · Arctic Ocean · Mackenzie River estuary · Picocyanobacteria · CARD-FISH

\section{INTRODUCTION}

Coastal arctic ecosystems are a focus of major environmental concern, given the increasing evidence of climatic impacts in the northern polar region (Serreze et al. 2000, Mueller et al. 2003) and model predictions that global climatic change will continue to accelerate, with the greatest effects at high northern latitudes (ACIA 2004). Throughout the last 25 yr there has been a steady downward trend in the extent of summer sea ice in coastal arctic regions, with 3 consecutive years of record minima in the period from 2002 to 2004 (Stroeve et al. 2005). The Arctic Ocean is strongly influenced by inflows from large rivers, and the discharge of these inputs appears to be increasing (Peterson et al. 2002), with implications for the delivery of dissolved and particulate organic matter to inshore arctic seas. Moreover, permafrost melting in subarctic and arctic catch- 
ments (Payette et al. 2004) may mobilize the large stocks of organic carbon contained within their soils and cause increased transfer of these materials to arctic rivers and ultimately to the ocean. Heterotrophic microbiota are likely to play a major role in the response of coastal arctic ecosystems to ongoing change, but prokaryotic diversity and production in these cold ocean environments have been little explored (Amon 2004).

In the western Canadian Arctic, the Mackenzie River discharges large quantities of freshwater, solutes and sediments into a vast shelf region of the Beaufort Sea that extends $>100 \mathrm{~km}$ offshore and encompasses a total area of $63600 \mathrm{~km}^{2}$ (Carmack et al. 2004). The annual discharge of the Mackenzie River $\left(330 \mathrm{~km}^{3} \mathrm{yr}^{-1}\right.$; Macdonald et al. 1998) is the 4th highest in the Arctic Basin after the Siberian rivers Yenisei, Lena and Ob, with concomitantly large inputs of freshwater biota, terrestrial nutrients, organic carbon and suspended sediment. Each year, the river transports an estimated 118 to $127 \times 10^{6} \mathrm{t}$ of sediments (Droppo et al. 1998, Macdonald et al. 1998) and $3 \times 10^{6} \mathrm{t}$ of dissolved and particulate organic carbon (Telang et al. 1991, Macdonald et al. 1998) onto the Beaufort Sea shelf. The physical and geochemical oceanography of this region is well documented (Carmack \& Macdonald 2002), and several reports exist concerning the upper trophic levels (Dickson \& Gilchrist 2002, Harwood \& Smith 2002, Stirling 2002). Many studies have examined the phytoplankton and zooplankton (Carmack et al. 2004 and references therein), but few have considered microbial communities and processes, and this lack of microbiological information has been identified as a major gap in understanding the structure and dynamics of this coastal arctic ecosystem (Amon 2004). Early studies of the microbiota were conducted in the western Beaufort Sea, at nearshore sites off Alaska, and were based on observations of bacterial isolates brought into culture (Kaneko et al. 1977, 1978a,b). At that time, the prokaryotic community structure could not be investigated further because of the lack of appropriate protocols. More recently, molecular techniques have been applied to the Arctic Ocean and have revealed a much broader range of taxa, including widespread Archaea (Bano \& Hollibaugh 2002, Wells \& Deming 2003, Bano et al. 2004).

Our objective in the present study was to evaluate the offshore pattern in prokaryotic community composition and production of the Mackenzie River plume. We hypothesized that the freshwater influence would give rise to strong gradients in salinity, dissolved organic carbon (DOC) and particle loading that, in turn, would affect community structure and productivity. We addressed this hypothesis by way of a transect analysis during autumn conditions of minimum ice cover and moderate river flow. Microbial production was estimated with shipboard incubations of water samples with ${ }^{3} \mathrm{H}$-leucine, and the offshore gradients in cell concentration of major taxonomic groups were determined by epifluorescence microscopy. Our approach included the application of a recently described molecular probe technique, the catalyzed reporter deposition for fluorescence in situ hybridization assay (CARD-FISH) (Pernthaler et al. 2002, Schippers et al. 2005). This method gives a much brighter detection of cells than the regular FISH approach, with values comparable to the application of polynucleotide probes (Pernthaler et al. 2002). Finally, we evaluated, by way of size-fractionation experiments, the proportion of microheterotrophic activity associated with particlebound versus free-living heterotrophic prokaryotes at 2 inshore, river-influenced sites.

\section{MATERIALS AND METHODS}

Sampling. The study was carried out from 22 September to 14 October 2002 in the Mackenzie shelf and Franklin Bay area (Fig. 1a), from the icebreaker CCGS 'Pierre Radisson' within the framework of the CASES project (Canada Arctic Shelf Exchange Study). Surface water samples were collected along a north-south transect composed of 2 river stations (Stn R1 in the East Channel above Inuvik, $120 \mathrm{~km}$ from the river mouth, and Stn R2, in the Main Channel, $90 \mathrm{~km}$ above the river mouth; sampling by ship-based helicopter), 3 coastal stations inside the $20 \mathrm{~m}$ isobath located at ca. $69^{\circ} 56^{\prime} \mathrm{N}$ (Stns Z1, Z2 and Z5; sampling by Zodiac) and 3 offshore stations (Stns 65, 66 and 49; sampling from the icebreaker). Inshore stations were sampled with a 51 Go-Flow bottle and a SBE-19 CTD (conductivity-temperature-depth) profiler. Offshore stations were sampled from the icebreaker using a SBE Carousel Rosette system of 24 PVC bottles each of 121 volume (Ocean Test Equipment) and equipped with a SBE911-plus CTD profiler. Surface salinity values were also obtained at 32 other stations over the entire CASES sampling area. Some comparative analyses were also made at a river-influenced coastal site in Franklin Bay, $270 \mathrm{~km}$ to the east of the transect (Stn 12; Fig. 1a).

Particulate and dissolved material. Samples for seston dry weight measurements were filtered onto pre-combusted and pre-weighed GF/F filters, rinsed with $10 \mathrm{ml}$ of $1 \%$ ammonium formate to dissolve salts and stored in plastic petri dishes at $-20^{\circ} \mathrm{C}$. The filters were subsequently dried at $60^{\circ} \mathrm{C}$ and re-weighed for final determination of suspended particulate matter (SPM) (Williams 1985). Samples for DOC determination were filtered through $0.2 \mu \mathrm{m}$ (standard pore size 

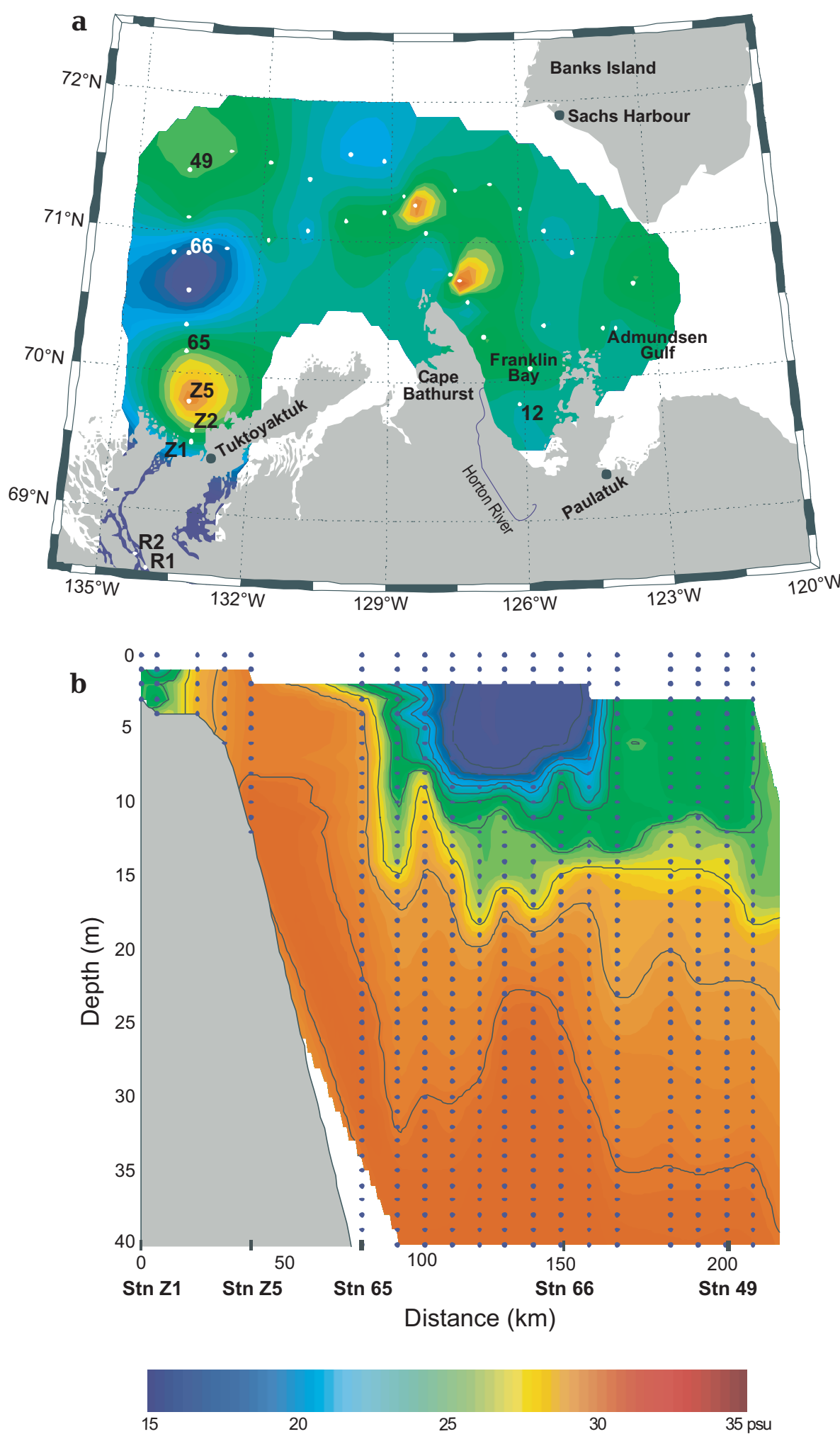

Fig. 1. (a) Location of the sampling stations. The salinity field was estimated by ordinary kriging (Marcotte 1991). We present only the extrapolated salinity values with an estimation error of $\leq 40 \%$. (b) Salinity section between Stns Z1 and 49. The vertical dotted lines show the location of the CTD profiles. Note the patch of fresher water 90 to $160 \mathrm{~km}$ offshore as adopted in other arctic studies) cellulose acetate filters (AMD Manufacturing), and the filtrate was stored in the dark at $4^{\circ} \mathrm{C}$ until analysis by high temperature combustion/direct injection in a gas analyzer (HTC/DI) (Knap et al. 1996), after acidification. Samples were then bubbled with $\mathrm{CO}_{2}$-free nitrogen for a prolonged period $(7 \mathrm{~min}$ ) to ensure the removal of all the dissolved inorganic carbon (DIC), as recommended for high DIC water (Knap et al. 1996). Analyses were done using a Shimadzu TOC Analyzer 5000A (detection limits of $0.05 \mathrm{mg} \mathrm{l}^{-1}$ ) at the Institut national de la recherche scientifique, Centre Eau, Terre et Environnement (Québec City, Canada).

Phototrophic bacterioplankton enumeration. Phytoplankton biomass was estimated from chlorophyll a (chl a) analysis of the total community and of the picophytoplankton fraction. Samples were filtered onto Whatman GF/F glass fiber filters before (chl $a_{\text {tot }}$ ) and after pre-filtration (chl $\left.a_{<3} \mu \mathrm{m}\right)$ through $47 \mathrm{~mm}, 3 \mu \mathrm{m}$ pore size, Nuclepore polycarbonate membranes. The filters were stored frozen $\left(-80^{\circ} \mathrm{C}\right)$ until pigment extraction in ethanol (Nusch 1980). Chl a concentration was determined by fluorometry before and after acidification (Strickland \& Parsons 1972) using a Cary Eclipse spectrofluorometer standardized with Anacystis chl a.

Samples for picocyanobacterial counts were pre-filtered through $3 \mu \mathrm{m}$ porosity membranes and then under low pressure onto $0.2 \mu \mathrm{m}$ Anodiscs. The filters were mounted in immersion oil on slides, which were sealed and stored frozen in the dark at $-20^{\circ} \mathrm{C}$. Picocyanobacteria were counted with a fluorescence microscope at $\times 1000$ in oil immersion, using green and blue exchangeable filter blocks to detect the presence of the phyocobilins of cyanobacteria and cryptophytes (Lovejoy et al. 2002). Picocyanobacteria fluoresced red under green light excitation and yellow under blue light, in contrast to photosynthetic picoeukaryotes that were red under both conditions. A minimum of 400 cells was counted on each slide. 
CARD-FISH analysis. Cell identification for the major prokaryotic groups was made by fluorescence in situ hybridization (FISH) using horseradish peroxidase (HRP)-labeled oligonucleotide probes combined with signal amplification by tyramide labeled with carboxyfluorescein. This catalyzed reporter deposition (CARD) approach offers advantages over the standard FISH assay by providing enhanced fluorescence intensities (Pernthaler et al. 2002). Samples were fixed onboard the ship for $24 \mathrm{~h}$ at $4^{\circ} \mathrm{C}$ in $2 \%$ formalin (final conc.), then filtered onto $0.2 \mu \mathrm{m}$ pore size, $47 \mathrm{~mm}$ diameter polycarbonate membranes and frozen at $-20^{\circ} \mathrm{C}$ until analysis. Sections were subsequently cut from each filter and hybridized with the HRP probes (as described in Pernthaler et al. 2002) specific to Archaea (Arch915), Bacteria (Eub338) and to 4 major phylogenetic lineages of this latter domain: the alpha $\left(\alpha ;\right.$ Alf968), beta ( $\beta$; Bet42a) and gamma ( $\gamma_{i}$ Gam42a) subclasses of the Proteobacteria and the CytophagaFlavobacter-Bacteroides cluster (CFB; CF319a). The sequences used for the probes are given in Table 1. Oligonucleotides labeled with HRP were obtained from www.biomers.net.

The polycarbonate filter sections were briefly dipped into aqueous, low-gelling point agarose solution $(0.1 \%$ $\mathrm{w} / \mathrm{w})$ at 35 to $40^{\circ} \mathrm{C}$ and then air dried. This treatment minimized cell detachment and loss from the filter during the subsequent permeabilization step. Permeabilization was done by incubation with lysozyme $\left(10 \mathrm{mg} \mathrm{ml}^{-1}\right)$ or Proteinase $\mathrm{K}$ for the detection of Archaea $\left(2360 \mathrm{U} \mathrm{mg}^{-1}, 9.85 \mathrm{mg} \mathrm{ml}^{-1}, 0.2 \mu \mathrm{ml}^{-1}\right.$ final conc.; Sigma) in a solution ( $\mathrm{pH}$ 8) of $50 \mathrm{mM}$ EDTA and $0.1 \mathrm{M}$ Tris-HCl for $60 \mathrm{~min}$ at $37^{\circ} \mathrm{C}$. Samples for Archaea detection were then incubated for $20 \mathrm{~min}$ in $0.01 \mathrm{M}$ $\mathrm{HCl}$ at room temperature to inactivate the Proteinase K. All the filter sections were hybridized for $2 \mathrm{~h}$ at $35^{\circ} \mathrm{C}$ with the selected HRP-oligonucleotide probe. The probe solution was made up at a concentration of $50 \mathrm{ng}^{-1} \mathrm{l}^{-1}$ in deionized water and then diluted 1:300 in a buffer composed of $900 \mathrm{mM} \mathrm{NaCl}, 20 \mathrm{mM}$ Tris- $\mathrm{HCl}$
$(\mathrm{pH} 8), 10 \%(\mathrm{w} / \mathrm{v})$ dextran sulfate, $0.02 \%(\mathrm{w} / \mathrm{v})$ sodium dodecyl sulfate (SDS), $1 \%(\mathrm{v} / \mathrm{v})$ blocking reagent (Roche 1096176) and 55\% (v/v) formamide.

After hybridization, the filter sections were soaked for $5 \mathrm{~min}$ in pre-heated $\left(37^{\circ} \mathrm{C}\right)$ washing buffer $(5 \mathrm{mM}$ EDTA [pH 8], $20 \mathrm{mM}$ Tris-HCl [pH 8], $0.01 \%$ [w/v] SDS) containing $3 \mathrm{mM} \mathrm{NaCl}$. The sections were then incubated in $50 \mathrm{ml}$ of phosphate-buffered saline solution $(1 \times$ PBS, pH 7.6; Catalogue No. P3744, Sigma) for $15 \mathrm{~min}$ at room temperature in order to equilibrate the probe-delivered HRP. In the final step, the sections were put in a reaction vial with 1000 parts of amplification buffer $(2 \mathrm{M} \mathrm{NaCl}, 10 \%$ [w/v] dextran sulfate, $1 \times$ PBS, $0.1 \%$ [v/v] blocking reagent, $0.0015 \% \mathrm{H}_{2} \mathrm{O}_{2}$ ) and 2 parts of tyramide-carboxyfluorescein $\left(1 \mathrm{mg} \mathrm{ml}^{-1}\right)$ and were incubated for $15 \mathrm{~min}$ at $46^{\circ} \mathrm{C}$. After a 15 min dark incubation, excess liquid was removed by placing the filter sections on blotting paper. Filter sections were first washed with deionized water and then with absolute ethanol, and then air-dried and mounted with 4:1 Citifluor:Vecta Shield containing $1 \mu \mathrm{g} \mathrm{ml}^{-1}$ of $4^{\prime}, 6-$ diamidino-2-phenylindole (DAPI).

In order to avoid non-specific hybridization with Bet42a and Gam42a probes, we used the competitor probe Bet42a when hybridizing Gam42a-stained cells and the competitor probe Gam42a when hybridizing Bet42a-stained cells (Manz et al. 1992). The slides were counted on a Zeiss Axioplan microscope with a $\times 1000$ Plan Apochromat objective (Carl Zeiss) under ultraviolet excitation for DAPI fluorescence and blue light for carboxyfluorescein from an HBO $100 \mathrm{~W} \mathrm{Hg}$ vapor lamp. To ensure a counting error of $<10 \%$, between 600 and 800 DAPI-stained objects were counted per sample (Pernthaler et al. 2001). For each oligonucleotide probe, results are expressed as: (1) total hybridized heterotrophic prokaryotes as detected by carboxyfluorescein fluorescence (cells $\mathrm{ml}^{-1}$ ) and (2) hybridized cells with the specific probe as a percentage of the total heterotrophic prokaryote (DAPI fluorescence) count on each filter section. Nega-

Table 1. Molecular horseradish peroxidase-labeled oligonucleotide probes used for the CARD-FISH (catalyzed reporter deposition fluorescence in situ hybridization) analysis in the study

\begin{tabular}{|llll|}
\hline Target taxa & Probe & Probe sequence (5'-3') & Source \\
\hline Bacteria $^{\mathrm{a}}$ & Eub338 & GCT GCC TCC CGT AGG AGT & Amann et al. (1990) \\
Archaea & Arch915 & GTG CTC CCC CGC CAA TTC CT & Stahl \& Amann (1991) \\
$\alpha$-Proteobacteria & Alf968 & GGT AAG GTT CTG CGC GTT & Neef (1997) \\
$\begin{array}{l}\text { }- \text {-Proteobacteria } \\
\text {-Proteobacteria }\end{array}$ & Bet42a & GCC TTC CCA CTT CGT TT & Manz et al. (1992) \\
Cytophaga-Flavobacter-Bacteroides & Gam42a & GCC TTC CCA CAT CGT TTT & Manz et al. (1992) \\
Negative control & Non338 & TGG TCC GTG TCT CAG TAC & Manz et al. (1996) \\
axcept Planctomycetales and Verrucomicrobia (Daims et al. 1999) & Wallner et al. (1993) \\
\hline
\end{tabular}


tive controls (hybridization with a non-specific probe) with the probe Non338 consistently yielded very few or no fluorescently labeled cells $(<0.3 \%$ of DAPIstained cells).

Duplicate counts of the probe-positive Eub338 and CF319a cells were made at 3 (Stns Z5, R1 and R2) and 2 (Stns Z5 and R2) stations, respectively. On average, the relative error on absolute counts (expressed in cells $\mathrm{ml}^{-1}$ ) was $7 \%$ for the Eub338-positive cells and 38\% for the CF319a-positive cells. The latter value was in large part due to the relative error on CF319a-positive counts at Stn R2 (54\%). The relative error on duplicate relative abundance (expressed as a percentage of hybridized heterotrophic prokaryote cells on total heterotrophic prokaryotes [\%Eub and \%CFB]) was also highest for the river samples $(\geq 20 \%)$. For all sampled stations, the mean cell counts $( \pm \mathrm{SD})$ were $77 \pm 5 \%$ for the relative abundance of Eubacteria and $12 \pm 2 \%$ for the relative abundance of CFB cells. Counts with the CF319a probe were subject to more error than those with the Eub338 probe.

We checked the potential cross-reactivity of our selected probes in the domain Bacteria in the Ribosomal Database (http://rdp.cme.msu.edu/index.jsp). This analysis showed that some Proteobacteria (145 sequences) were also targeted by the CF319a probe, but this represented only $3 \%$ of its potential targets and many were from unusual hydrothermal vent environments. The analysis further showed that $13 \%$ of the total targets for Alf968 were outside the $\alpha$-Proteobacteria group, and included a cyanobacterium found in the Antarctic, 12 sequences of planktomycetes found in Antarctic continental shelf sediments and many $\delta$-Proteobacteria. The archaeal probe Arch915 targeted only 4 sequences in the domain Bacteria. The probe for $\beta$-Proteobacteria found no matching sequences among those currently entered in the database.

Heterotrophic prokaryote counts. At each station, total prokaryotic cells were enumerated: (1) by DAPI staining of formalin-fixed samples ( $2 \%$ final conc.) and filtering through $0.2 \mu \mathrm{m}$ white polycarbonate membranes without the CARD-FISH procedures ( $\left.\mathrm{HP}_{\text {formalin }}\right)$ and (2) by the same DAPI staining, fixing and filtration, but after the CARD-FISH procedures $\left(\mathrm{HP}_{\mathrm{FISH}}\right)$. The $\mathrm{HP}_{\mathrm{FISH}}$ counts were on average equivalent to $80 \%$ of the $\mathrm{HP}_{\text {formalin }}$ counts, indicating that the CARD-FISH technique did not induce significant losses and attesting to the attachment efficiency of the agarose gel treatment. Total heterotrophic prokaryote cells were estimated from the samples that did not undergo CARD-FISH treatment ( $\left.\mathrm{HP}_{\text {formalin }}\right)$.

Heterotrophic production. Heterotrophic activity of prokaryotes was determined by measurements of ${ }^{3} \mathrm{H}$-leucine uptake and incorporation into protein (Kirchman \& Ducklow 1993), following the Knap et al.
(1996) protocol. Archaea are known to take up amino acids at natural ambient concentrations (Ouverney \& Fuhrman 2000), as is the case for the major phylogenetic groups of Bacteria (Cottrell \& Kirchman 2003). Recent results show that production rates estimated with the ${ }^{3} \mathrm{H}$-leucine method can be considered as total prokaryotic production, including the contribution of both Bacteria and Archaea (Herndl et al. 2005).

Under low light conditions, $50 \mathrm{ml}$ sample volumes were dispensed into incubation flasks and inoculated with ${ }^{3} \mathrm{H}$-leucine (specific activity, $60 \mathrm{Ci} \mathrm{mmol}^{-1}$ ) at a final concentration of $10 \mathrm{nM}$. Triplicate samples were then incubated in the dark at $0^{\circ} \mathrm{C}$ for $2 \mathrm{~h}$. This temperature was close to or slightly above ambient for the marine samples $\left(0\right.$ to $\left.-1.4^{\circ} \mathrm{C}\right)$, but slightly below ambient for the river samples $\left(2.9\right.$ to $\left.3.9^{\circ} \mathrm{C}\right)$. Incubations were terminated by adding trichloracetic acid (TCA, $5 \%$ final conc.), and samples were then heated to $80^{\circ} \mathrm{C}$ for $15 \mathrm{~min}$. All killed samples, including time zero controls, were filtered onto $25 \mathrm{~mm}, 0.22 \mu \mathrm{m}$ pore size cellulose nitrate filters, rinsed 3 times with ice-cold $5 \%$ TCA and then with ice-cold ethanol and kept at $-20^{\circ} \mathrm{C}$ in $7 \mathrm{ml}$ vials. The filters were subsequently dried in their vials at $20^{\circ} \mathrm{C}$ overnight and dissolved in $0.5 \mathrm{ml}$ of ethyl acetate. Ready Safe scintillation cocktail (Beckman) was added, and samples were radio-assayed. Heterotrophic production rates were calculated using the conversion factor of $3.1 \mathrm{~kg} \mathrm{C} \mathrm{mol}{ }^{-1}$ of ${ }^{3} \mathrm{H}$-leucine (Kirchman \& Ducklow 1993). A fractionation experiment was conducted at 2 inshore sites (Stns Z2 and 12) to determine the importance of particle-bound microbiota for heterotrophic production. The ${ }^{3} \mathrm{H}$-leucine substrate was added to triplicate $50 \mathrm{ml}$ samples that had been pre-filtered through $3 \mu \mathrm{m}$ membranes and to triplicate unfiltered samples. These samples were then incubated and processed as above.

Statistical analysis. Association between pairs of variables was measured with the Pearson moment product correlation ( $\mathrm{r}$ coefficient) for all variables, since we found no large deviations from normality (Zar 1999). Partial correlations were run to examine the interactions between 3 variables, and in order to remove spurious correlations. First-order partial correlation considers the relation between 2 variables, while holding constant the value of a third variable (Zar 1999). The partial correlation coefficient (expressed as $\mathrm{r}_{X . Y \mid Z}$ ) represents the relationship between the variables $X$ and $Y$, while holding the variable $Z$ constant. If the partial correlation coefficient approaches 0 , there is no direct causal link between the variables $X$ and $Y$ because the variable $Z$ is either a common anteceding or intervening variable. Significance tests for the firstorder partial coefficients were made with Student's t-test with df $=\mathrm{n}-3$ (Myers \& Well 2003). Linear regressions were done on paired variables for which it 
Table 2. Environmental characteristics and chlorophyll a concentrations for surface waters in the Mackenzie River, Beaufort Sea shelf and Franklin Bay (Stn 12) at the times of sampling. SPM: suspended particulate matter; DOC: dissolved organic matter; chl $a$ : chlorophyll $a_{i}$ chl $a_{<3 \mu \mathrm{m}}$ : chl $a$ value for the $<3 \mu \mathrm{m}$ fraction; -: no data available

\begin{tabular}{|lccccccc|}
\hline Stn & Date & $\begin{array}{c}\text { Temp. } \\
\left({ }^{\circ} \mathrm{C}\right)\end{array}$ & $\begin{array}{c}\text { Salinity } \\
(\mathrm{psu})\end{array}$ & $\begin{array}{c}\mathrm{SPM} \\
\left(\mathrm{mg} \mathrm{l}^{-1}\right)\end{array}$ & $\begin{array}{c}\mathrm{DOC} \\
\left(\mathrm{mg} \mathrm{C}^{-1}\right)\end{array}$ & $\begin{array}{c}\mathrm{Chl} a \\
\left(\mu \mathrm{g} \mathrm{l}^{-1}\right)\end{array}$ & $\begin{array}{c}\mathrm{Chl} a_{<3 \mu \mathrm{m}} \\
(\% \text { total })\end{array}$ \\
\hline $\mathrm{R} 1$ & 8 Oct & 2.9 & 0.2 & 42.5 & 5.7 & 1.30 & 30 \\
$\mathrm{R} 2$ & 8 Oct & 3.9 & 0.2 & 27.8 & 4.9 & 1.29 & 22 \\
$\mathrm{Z} 1$ & 2 Oct & -0.04 & 24.5 & 60.4 & 1.6 & 1.39 & - \\
$\mathrm{Z} 2$ & 3 Oct & -0.54 & 25.4 & 17.3 & 2.5 & 0.51 & 35 \\
$\mathrm{Z} 5$ & 3 Oct & -1.3 & 30.1 & 12.7 & 1.2 & 0.24 & $37^{\mathrm{a}}$ \\
65 & 2 Oct & -0.32 & 26.9 & 1.8 & 0.9 & 0.21 & 58 \\
66 & 4 Oct & -0.61 & 20.3 & - & - & 0.54 & 60 \\
49 & 28 Sep & -0.67 & 26.3 & 1.0 & 1.1 & 0.06 & 67 \\
12 & 12 Oct & -1.3 & 23.4 & 9.3 & - & 0.51 & 34 \\
${ }^{\mathrm{a}} \mathrm{Chl} a$ value for the $<5 \mu \mathrm{m}$ fraction & & & & \\
\hline
\end{tabular}

transect line is the result of the isopleth plotting algorithm and must be interpreted with caution. However, the transect surface data clearly show an offshore patch of fresher water (Stn 66) separated from the shore by a zone of higher salinity (Stn 65). This effect is further seen in the hydrographic section (Fig. 1b), which suggests that the high salinity values separating the freshwater-influenced stations (Stns Z5 and 65) may have been due to an upwelling event forced by winds. Consistent with this possibility, meteorological data recorded at Tuktoyaktuk in 2002 show that easterly winds of moderate intensity (on average $15 \mathrm{~km} \mathrm{~h}^{-1}$ ) started on 23 Sep- was possible to determine the independent variable (salinity, temperature, etc.). One-way ANOVA or the non-parametric Kruskal-Wallis test was used to test differences among sampling regions.

\section{RESULTS}

\section{Physico-chemical conditions}

At the time of sampling, the Mackenzie River estuary was ice-free and strong southerly winds had pushed the perennial pack ice well offshore, to $31 \mathrm{~km}$ north of Stn 49. The seasonal freezing of the Mackenzie River had not begun at this time, although ice had started to form on the delta lakes. Average flows in September are typically around $12000 \mathrm{~m}^{3} \mathrm{~s}^{-1}$, which amounts to $30 \%$ of peak discharge in early June (Macdonald \& Yu in press). The surface water characteristics at our stations ranged from fresh to fully marine (Table 2). However, there was no continuous offshore increase in salinity, but rather an immediate rise in salinities at inshore stations (Stns Z1, Z2 and 65), then a decrease in salinity at Stn 66, before a return to higher salinities at Stn 49. The salinity field (Fig. 1a) suggests that the Mackenzie River plume discharging from the western side of the river mouth (the main channel that receives the greatest flow) may have been deflected back eastwards into the study region, giving rise to a salinity minimum near Stn 66, 150 km offshore. It should be noted that the salinity pattern in the section west of the tember and lasted for $10 \mathrm{~d}$ (Environment Canada 2002). This period included the sampling dates for all offshore and coastal stations, except Stn 66, which was sampled $1 \mathrm{~d}$ later on 4 October. Over the entire sampling period, there was a strong inverse correlation between salinity and temperature $(\mathrm{r}=-0.97$, $\mathrm{p}<0.0001)$. The riverine freshwaters were relatively warm $\left(2\right.$ to $\left.4^{\circ} \mathrm{C}\right)$, whereas coastal and offshore station surface waters were $<0^{\circ} \mathrm{C}$.

\section{Chl a, DOC and SPM}

Total chl a concentrations in the surface waters were low (0.06 to $1.39 \mathrm{\mu g} \mathrm{l}^{-1}$; Table 2) and strongly correlated with SPM concentrations $(r=0.91, p<0.005)$. Small cells $(<3 \mu \mathrm{m})$ contributed between 22 and $67 \%$ of the total chl a concentration and dominated (>50\%) the phytoplankton community at offshore stations (Table 2). Chl $a$ in this small cell fraction was also
Table 3. Mean values at river (R1, R2), coastal (Z1, Z2, Z5) and offshore stations $(65,66,49)$ for environmental and biological variables. The 1-way ANOVA results are indicated for significant difference between means $(\neq)$. ns: no significant difference; SPM: suspended particulate matter; DOC: dissolved organic matter; chl a: chlorophyll $a_{\text {; }}$ chl $a_{<3 \mu \mathrm{m}}$ : chl $a$ value for the $<3 \mu \mathrm{m}$ fraction

\begin{tabular}{|c|c|c|c|c|}
\hline \multirow[t]{2}{*}{ Variable } & \multicolumn{3}{|c|}{$\longrightarrow$ Stn -} & \multirow{2}{*}{$\begin{array}{l}\text { ANOVA } \\
(\mathrm{p} \leq 0.05)\end{array}$} \\
\hline & River & Coastal & Offshore & \\
\hline Temperature $\left({ }^{\circ} \mathrm{C}\right)$ & 3.4 & -0.61 & -0.53 & $\mathrm{R} \neq \mathrm{C}, \mathrm{R} \neq \mathrm{O}$ \\
\hline Salinity (psu) & 0.2 & 26.8 & 24.5 & $\mathrm{R} \neq \mathrm{C}, \mathrm{R} \neq \mathrm{O}$ \\
\hline $\operatorname{SPM}\left(\mathrm{mg} \mathrm{l}^{-1}\right)$ & 35.2 & 30.1 & 1.4 & ns \\
\hline $\mathrm{DOC}\left(\mathrm{mg} \mathrm{Cl}^{-1}\right)$ & 5.3 & 1.7 & 1.0 & $\mathrm{R} \neq \mathrm{C}, \mathrm{R} \neq \mathrm{O}$ \\
\hline $\operatorname{Chl} a\left(\mu g \mathrm{l}^{-1}\right)$ & 1.29 & 0.71 & 0.27 & ns \\
\hline Chl $a_{<3 \mu \mathrm{m}}(\%$ total $)$ & 26 & 26 & 61 & $\mathrm{R} \neq \mathrm{O}, \mathrm{C} \neq \mathrm{O}$ \\
\hline $\begin{array}{l}\text { Heterotrophic prokaryotes } \\
\left(\text { cells ml }{ }^{-1}\right)\end{array}$ & $1.3 \times 10^{6}$ & $4.3 \times 10^{5}$ & $2.3 \times 10^{5}$ & $\mathrm{R} \neq \mathrm{C}, \mathrm{R} \neq \mathrm{O}$ \\
\hline
\end{tabular}


Table 4. Abundance of phototrophic and heterotrophic prokaryotes in the Mackenzie River, the Beaufort Sea shelf and in Franklin Bay (Stn 12). Heterotrophic prokaryotes were the total DAPI-stained cell counts from samples that did not undergo CARD-FISH treatment $\left(\mathrm{HP}_{\text {formalin }}\right)$. Percentages of Archaea and Bacteria were calculated from the total DAPI counts (heterotrophic prokaryotes, $\mathrm{HP}_{\mathrm{FISH}}$ ) after CARD-FISH treatment with the appropriate probe

\begin{tabular}{|ccccc|}
\hline Stn & $\begin{array}{c}\text { Picocyano- } \\
\text { bacteria } \\
\left(10^{2} \text { cells ml }^{-1}\right)\end{array}$ & $\begin{array}{c}\text { Heterotrophic } \\
\text { prokaryotes } \\
\left(10^{5} \text { cells ml }{ }^{-1}\right)\end{array}$ & $\begin{array}{c}\text { Bacteria } \\
(\% \text { FISH })\end{array}$ & $\begin{array}{c}\text { Archaea } \\
\left(\% P_{\text {FISH }}\right)\end{array}$ \\
\hline R1 & 35.0 & 18.1 & 52 & 6.3 \\
R2 & 67.1 & 14.0 & 64 & 5.3 \\
Z1 & 3.9 & 5.7 & 83 & 5.1 \\
Z2 & 23.3 & 3.9 & 83 & 6.4 \\
Z5 & 6.6 & 3.6 & 74 & 6.9 \\
65 & 4.0 & 3.6 & 86 & 2.2 \\
66 & 21.2 & 1.9 & 88 & 1.1 \\
49 & 2.3 & 2.1 & 87 & 0.6 \\
12 & 14.3 & 6.3 & 92 & 2.2 \\
\hline
\end{tabular}

The spatial distribution of heterotrophic prokaryotes in the river plume generally followed the DOC concentrations $(r=0.96$, $p<$ 0.001). Partial correlation analysis suggested that there was a stronger relationship with DOC; however, neither partial correlation coefficient was significant $\left(\left.\mathrm{r}_{\text {prokaryotes.DOC }}\right|_{\text {sal }}=\right.$ $0.72, \mathrm{p}=0.1$ and $\mathrm{r}_{\text {prokaryotes.sal }} \mid \mathrm{DOC}=0.21, \mathrm{p}=$ 0.7). Although heterotrophic prokaryote abundance was significantly correlated with temperature $(\mathrm{r}=0.93, \mathrm{p}<0.001)$, the partial correlation coefficient between these 2 variables was not significant when holding salinity constant $\left(\left.\mathrm{r}_{\text {prokaryotes.temp }}\right|_{\text {sal }}=0.39, \mathrm{p}=0.4\right)$. Heterotrophic prokaryote abundance was also strongly related to chl a concentrations ( $\mathrm{r}=$ 0.76, p < 0.05).

Picocyanobacteria abundance was strongly and inversely correlated with salinity ( $\mathrm{r}=$ $-0.89, p<0.005)$ and to a lesser extent with

correlated with SPM ( $\mathrm{r}=0.95, \mathrm{p}<0.01)$ and additionally with DOC $(r=0.96, p<0.01)$. There was no significant correlation between chl a (either fraction) and salinity.

DOC concentrations were similar at coastal and offshore marine stations ( $<1.8 \mathrm{mg} \mathrm{C} \mathrm{l}^{-1}$; Table 3$)$, whereas the river stations (Stns R1 and R2) had 5-fold higher DOC concentrations (Table 2). The river stations also had the highest SPM load (35.2 $\mathrm{mg} \mathrm{l}^{-1}$ ). There were large differences in SPM loading between the coastal and offshore stations, with mean values of 30.1 and $1.36 \mathrm{mg} \mathrm{l}^{-1}$, respectively (Table 3 ). Highest SPM concentrations were observed at the inshore marine station (Stn Z1). There was no significant correlation between SPM and salinity, and particulate loads at the river stations were of the same order as those at the coastal sites (Table 3).

\section{Picoplankton abundance and distribution}

In terms of cell abundance, heterotrophic prokaryotes dominated the picoplankton community of the Mackenzie River and shelf by 2 to 4 orders of magnitude over picocyanobacteria. Heterotrophic prokaryote abundance ranged from 1.9 to $18.1 \times 10^{5} \mathrm{cells} \mathrm{ml}^{-1}$, with a mean value of $6.6 \times 10^{5}$ cells $\mathrm{ml}^{-1}$, and picocyanobacteria, from 0.23 to $6.7 \times 10^{3}$ cells $\mathrm{ml}^{-1}$,

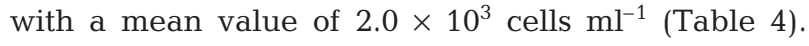
There was no significant difference in picophytoplankton abundance among the 3 groups of stations, but total heterotrophic prokaryote cell abundance was highest (ANOVA; $\mathrm{p}<0.05$ ) in river surface water (Table 3), decreasing gradually from the river to offshore stations (Table 4). temperature $(r=0.86, p<0.01)$, the warmer and fresher water having the greatest cell numbers. However, with the effect of salinity removed, the correlation between picocyanobacteria and temperature became nonsignificant $\left(\left.\mathrm{r}_{\text {picocyano.temp }}\right|_{\text {sal }}=0.05, \mathrm{p}=0.9\right)$. The salinity and the DOC concentration correlated with about the same strength with picocyanobacterial abundance $\left(\left.\mathrm{r}_{\text {picocyano.DOC }}\right|_{\text {sal }}=0.44\right.$ and $\left.\left.r_{\text {picocyano.sal }}\right|_{\text {temp }}=-0.39\right)$, but the coefficients were not significant at $\mathrm{p}<0.05$.

\section{Heterotrophic prokaryote community composition}

The general eubacterial probe (Eub338) detected, on average, $77 \%$ (range: 52 to $88 \%$ ) of the total DAPIstained cells (Table 4). The percentage of cells that hybridized with the Eub338 probe (hereafter referred to as Bacteria) was significantly lower at the river stations (mean value of $58 \%$ ) than at coastal (80\%) or at offshore $(87 \%)$ stations. Bacterial abundance varied between $1.7 \times 10^{5}$ and $6.9 \times 10^{5}$ cells ml $^{-1}$ (Table 4 ). The highest abundances were found at the river stations (mean of $6.3 \times 10^{5}$ cells $\mathrm{ml}^{-1}$ ) and were significantly $(\mathrm{p}<$ 0.05 ) higher than those at coastal and offshore stations (mean of $2.4 \times 10^{5}$ cells $\mathrm{ml}^{-1}$ ). As observed with total heterotrophic prokaryote abundance, the abundance of Bacteria was more related to DOC concentration $(\mathrm{r}=$ 0.97, $\mathrm{p}<0.001)$ than to temperature $(\mathrm{r}=0.91, \mathrm{p}<0.05)$ or salinity $(\mathrm{r}=-0.88, \mathrm{p}<0.005)$ across the river plume. This was also indicated by the partial correlation analysis $\left(\left.\mathrm{r}_{\text {bact.DOC }}\right|_{\text {sal }}=0.72, \mathrm{p}=0.1\right)$. Conversely, the relative abundance of Bacteria decreased with increasing DOC concentration $\left(\mathrm{r} \%\right.$ bact.DOC $\left.\left.\right|_{\text {sal }}=-0.77, \mathrm{p}=0.07\right)$.

The Archaea probe (Arch915) hybridized, on average, $4.0 \%$ of the total DAPI-stained cells (Table 4 ). 
The relative abundance of Archaea at offshore stations $(1.3 \%)$ was significantly different (ANOVA $;$ p < 0.05) from that at the river and coastal stations (averages of 5.8 and $6.1 \%$, respectively). Archaeal cell concentrations varied by 2 orders of magnitude among sites, with

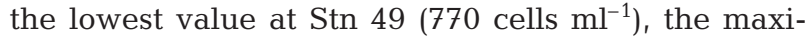
mum at Stn Z5 (7253 cells $\mathrm{ml}^{-1}$; Table 4) and a positive correlative relationship with SPM concentration ( $\mathrm{r}=$ $0.79, \mathrm{p}<0.05$ ).

Taken together, the Eub338 and the Arch915 probes should hybridize all prokaryotic cells in the samples. However, for the river samples, the total percentage of DAPI-positive cells for the sum of the 2 probes was, on average, $63 \%$, a value significantly lower $(\mathrm{p}<0.05)$ than the total percentage at coastal and offshore stations (86 and $88 \%$, respectively). A major fraction of the prokaryotes not detected with the Eub338 probe in river samples might belong to the Actinobacteria group. These bacteria are common in lakes and rivers (Zwart et al. 2002, Sekar et al. 2003), and their Grampositive cell walls may not be adequately permeabilized by lysozyme during the CARD-FISH procedure (Sekar et al. 2003). A study including a permeabilization by achromopeptidase identified, on average, $45 \%$ of prokaryotes as Actinobacteria in lake picoplankton (Sekar et al. 2003), concordant with the magnitude of our unidentified river fraction. In all our samples, the 4 specific probes in the domain Bacteria (Alf968, Bet42a, Gam42a and CF319a) taken together hybridized, on average, $55 \%$ (range: 23 to $78 \%$ ) of the total of DAPIstained cells. Specifically, at the 2 river stations, the 4 Bacteria-domain probes detected only $25 \%$ of the total DAPI counts, thus leaving about $75 \%$ of the counts unidentified and indicating the importance of other groups. At the other stations, $>42 \%$ of the DAPI-stained cells were detected with the $\alpha-, \beta-, \gamma$-Proteobacteria, or CFB probe.

$\beta$-Proteobacteria were the most abundant bacterial cells at the freshwater stations (Stns R1 and R2). Their abundance ranged from $4.1 \times 10^{3}$ to $2.9 \times 10^{5}$ cells $\mathrm{ml}^{-1}$, and their maximum numbers were found at the river stations (ANOVA; $\mathrm{p}<$ $0.05)$, where they constituted $18 \%$ of total DAPI-positive cells. Overall, the relative abundance of $\beta$-Proteobacteria was low, ranging from 1 to $18 \%$. Although no significant differences were found between sampled regions, the relative abundance of $\beta$-Proteobacteria generally decreased down the river plume (Fig. 2), showing a strong overall correlation with salinity $(\mathrm{r}=-0.98$, $\mathrm{p}<0.001)$, as well as a strong and significant partial correlation with salinity $\left(\left.\mathrm{r} \%_{\text {beta.sal }}\right|_{\text {temp }}=-0.76, \mathrm{p}<0.05\right)$. Offshore, at Stn 66, a re-emergence of $\beta$-Proteobacteria $\left(1.2 \times 10^{4}\right.$ cells $\mathrm{ml}^{-1} ; 6 \%$ of DAPI-positive cells) was observed, corresponding to an area of lower salinity (20.3 psu) relative to the adjacent Stns 65 and 49 .

The relative abundances of $\alpha$-Proteobacteria, $\gamma$-Proteobacteria and CFB were lowest at the river stations (Fig. 2). The $\alpha$-Proteobacteria cells ranged from 2 to $41 \%$ of total DAPI counts, and the absolute cell counts

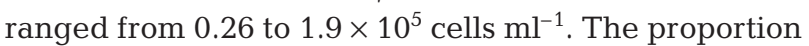
of $\alpha$-Proteobacteria tended to increase with salinity ( $\mathrm{r}=$ $0.76, \mathrm{p}<0.05)$ and to decrease with DOC concentration $(\mathrm{r}=-0.84, \mathrm{p}<0.05)$. At river stations, they represented only $2 \%$ of total cells, which was significantly lower than the relative abundance observed at coastal and offshore stations (ANOVA; $\mathrm{p}<0.05$ ). With a mean value of $39 \%$ of total DAPI-stained cells, the $\alpha$-Proteobacteria dominated all targeted heterotrophic prokaryote groups at offshore stations.

The relative abundances of the $\gamma$-Proteobacteria and CFB cluster across the Beaufort Sea shelf were similar to $\alpha$-Proteobacteria values (Fig. 2). For both bacterial groups, significantly lower relative abundance occurred at river stations $(\leq 3 \%)$ compared to at coastal and offshore stations (mean values of 16 and $17 \%$, respectively), and the latter 2 regions were statistically the same. Abundances of the $\gamma$-Proteobacteria (1.6 to $11.9 \times$ $10^{4}$ cells ml ${ }^{-1}$ ) and CFB cluster (1.6 to $8.4 \times 10^{4}$ cells $\mathrm{ml}^{-1}$ ) were within a similar range, with a mean value of

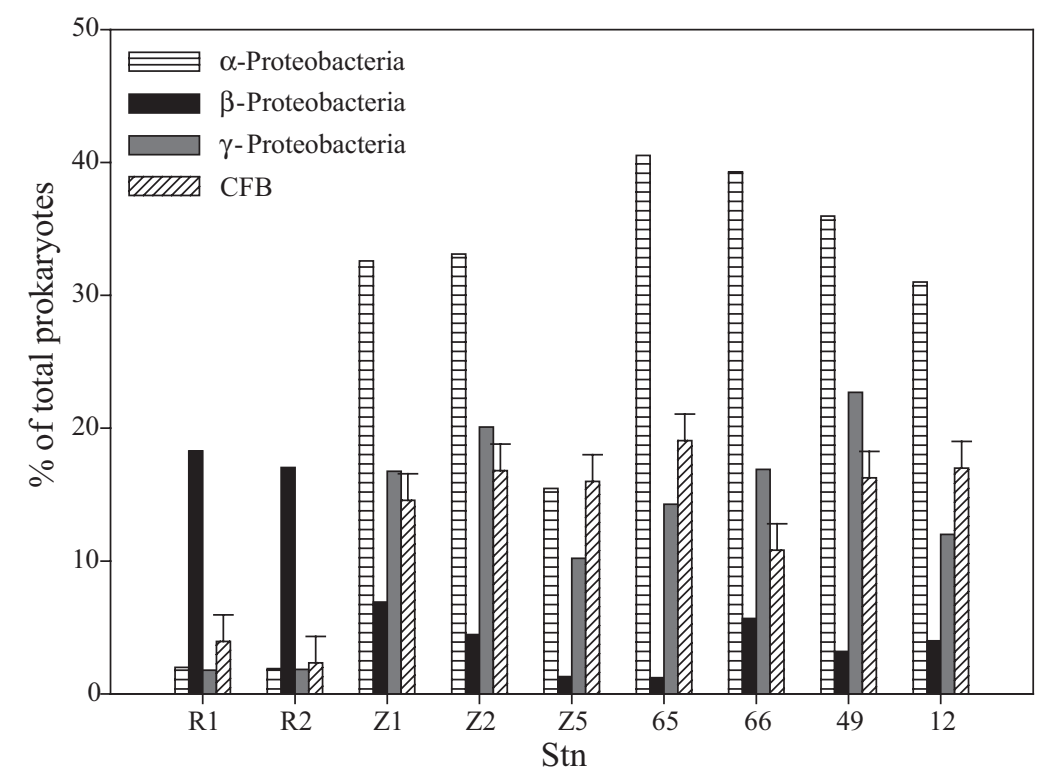

Fig. 2. Contribution of the 4 targeted groups of Bacteria ( $\alpha$-Proteobacteria, $\beta$ Proteobacteria, $\gamma$-Proteobacteria and the Cytophaga-Flavobacter-Bacteroides [CFB] cluster) to total heterotrophic prokaryote abundance along the Mackenzie River shelf transect and in Franklin Bay (Stn 12). Bars show the standard deviation for duplicate CFB counts 

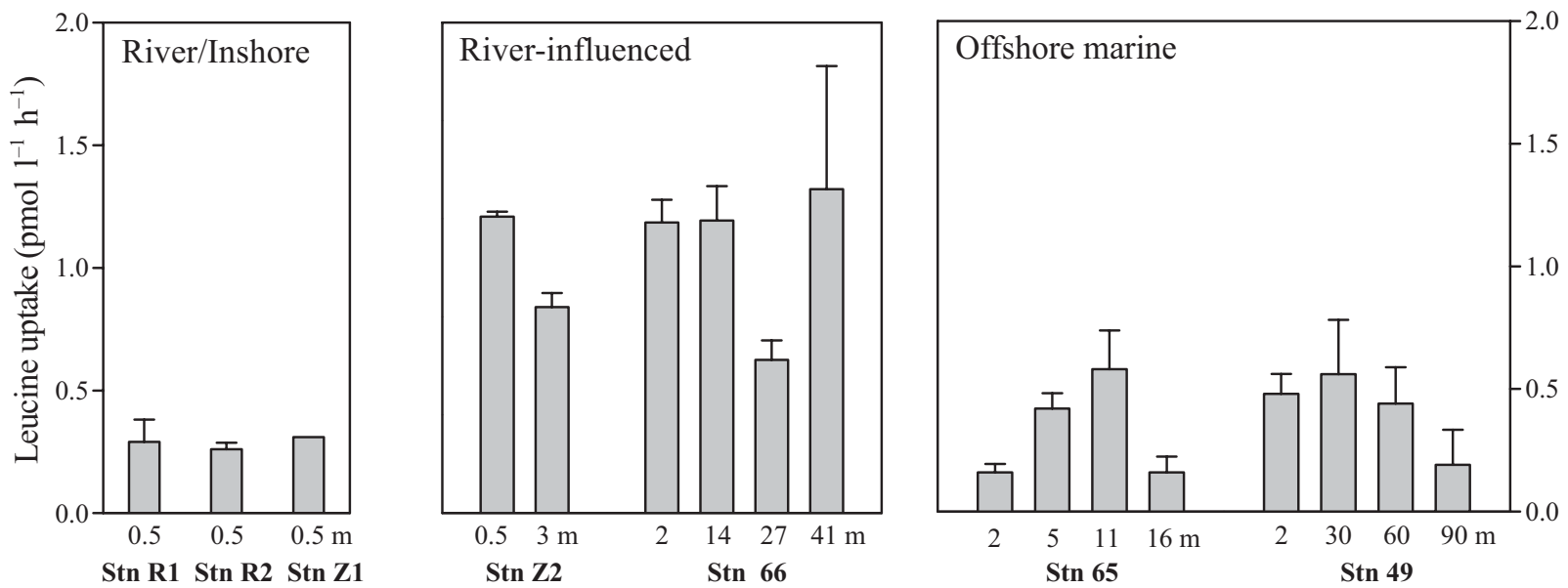

Fig. 3. ${ }^{3} \mathrm{H}$-leucine uptake at 3 groups of stations across the transect. Values $( \pm \mathrm{SE})$ are the means of triplicate incubations at $0^{\circ} \mathrm{C}$. At the 2 offshore marine stations, the sampled depths were equivalent to the euphotic zone depths of approximately 100, 10, 1 and $0.1 \%$ of surface irradiance. Environmental data for the surface waters at each station are given in Table 2

ca. $4.5 \times 10^{4}$ cells $\mathrm{ml}^{-1}$. As for $\alpha$-Proteobacteria, the relative abundance of CFB cells was significantly correlated with salinity $(\mathrm{r}=0.96, \mathrm{p}<0.001)$. There was no significant correlation between $\gamma$-Proteobacteria and the measured environmental variables.

Prokaryote community structure at the coastal station (Stn 12) in Franklin Bay was similar to that at the other marine sites and was characterized by the strong presence of $\alpha$-Proteobacteria (31\%). At this station, $4 \%$ of the total prokaryotes belonged to the $\beta$-Proteobacteria, suggesting a freshwater influence. This station was near the mouth of the Horton River (at $70^{\circ} \mathrm{N}, 127^{\circ} \mathrm{W}$; Fig. 1a) and may have received water from that source or from the Mackenzie River much further to the west. Archaea were also detected, making up $2.2 \%$ of the DAPI-stained cells (Fig. 2). This, in combination with high SPM and picocyanobacterial counts (Tables $3 \& 4$ ), is also consistent with a riverine influence at this station.

\section{Heterotrophic production}

Our analysis of the ${ }^{3} \mathrm{H}$-leucine uptake data indicated that the transect stations could be clustered into 3 groups that differed from the preceding environmental separation (Fig. 3). Stns R1, R2 and Z1 had similarly low uptake rates, around $0.5 \mathrm{pmol}^{-1} \mathrm{~h}^{-1}$. The coastal stations (Stns Z2 and 66) had 3-fold higher production rates, both at the surface and at depth, while the marine offshore stations (Stns 65 and 49) averaged values similar to those in the first cluster, but with considerable depth variation within their respective euphotic zones. Heterotrophic production rates at the surface, computed from the ${ }^{3} \mathrm{H}$-leucine uptake rates,
Table 5. Size-fractionated ${ }^{3} \mathrm{H}$-leucine uptake at 2 coastal stations. Each value is the mean of triplicates $( \pm \mathrm{SE})$

\begin{tabular}{|lcc|}
\hline Fraction & Stn Z2 & Stn 12 \\
\hline Total $\left(\mathrm{pmol} \mathrm{l}^{-1} \mathrm{~h}^{-1}\right)$ & $1.51 \pm 0.11$ & $3.13 \pm 0.27$ \\
$<3 \mu \mathrm{m}\left(\mathrm{pmol} \mathrm{l}^{-1} \mathrm{~h}^{-1}\right)$ & $0.48 \pm 0.10$ & $0.70 \pm 0.07$ \\
$>3 \mu \mathrm{m}(\%$ total $)$ & 68 & 78 \\
\hline
\end{tabular}

ranged from 12 (Stn 65) to 112 (Stn Z2) $\mu \mathrm{g} \mathrm{C} \mathrm{m} \mathrm{C} \mathrm{d}^{-1}$, with a mean value of $48 \mu \mathrm{g} \mathrm{C} \mathrm{m} \mathrm{m}^{-3} \mathrm{~d}^{-1}$.

The size fractionation experiment at Stn Z2 showed that about $2 / 3$ of the total leucine uptake activity was associated with particles in the $>3 \mu \mathrm{m}$ fraction (Table 5). The comparative measurements made in Franklin Bay (Stn 12) showed a >2-fold higher production rate by the total community compared to any of the samples along the transect. However, similar to the results at Stn Z2, most of the uptake in samples from this site was by microbiota in the $>3 \mu \mathrm{m}$ fraction.

\section{DISCUSSION}

Our transect analysis in the coastal arctic ecosystem of the Mackenzie River and Beaufort Sea shelf revealed strong spatial gradients in environmental properties and in prokaryotic communities in terms of abundance and composition. The river sites were up to $4^{\circ} \mathrm{C}$ warmer than the inshore marine sites, and contained markedly higher concentrations of DOC and prokaryotes. The offshore marine sites contained much lower sediment loads than inshore or river sites, but concentrations of chl $a$ and heterotrophic prokaryotes 
were similar to those at the inshore sites. The freshwater communities were dominated by the bacterial group $\beta$-Proteobacteria, which dropped to low abundance at all marine stations. Conversely, $\alpha$-Proteobacteria was the dominant bacterial group in the marine samples, together with strong representation by bacteria of the CFB and $\gamma$-Proteobacteria groups. These 3 groups of taxa were of minor importance in the river.

These transect results are broadly consistent with our hypothesis of coupled gradients in environmental and microbiological properties in the coastal Arctic Ocean. However, the spatial pattern observed in the leucine uptake data indicates a finer scale differentiation of marine sites, and deviation from a simple, continuous gradient with distance offshore. Specifically, the peak in microbial production $165 \mathrm{~km}$ offshore (Stn 66) was accompanied by cyanobacterial concentrations 1 order of magnitude higher, 3-fold higher concentrations of $\beta$-Proteobacteria and $50 \%$ lower concentrations of $\alpha$-Proteobacteria relative to Stn 65 , which was situated $80 \mathrm{~km}$ closer to the coast. Although far offshore, environmental characteristics at Stn 66 were similar to conditions observed inshore at the freshwater-influenced stations (Stns Z2 and 12). Stn 12 was probably affected by inputs from the nearby Horton River, as well as from the eastward flow from the Mackenzie River. All of these results are consistent with the lower salinity at Stn 66 and the far offshore intrusion into the study region of a freshwater plume, the latter possibly derived from the main channel of the Mackenzie River (Fig. 1a) and cut off from inshore waters by coastal upwelling (Fig. 1b). Extensive plumes are well known from other arctic sites; for example, the Lena River plume extends up to $400 \mathrm{~km}$ offshore over the Siberian shelf (Cauwet \& Sidorov 1996). Our hydrographic data at the time of sampling show that the salinity at Stn Z5 was the same as that found further offshore, at depths from 20 and $30 \mathrm{~m}$. This suggests a region of inshore upwelling that isolated the river-influenced waters offshore. Winds from the east entering the Beaufort Sea are known to produce such coastal upwelling, and the resulting instability permits the effective transfer of river water and sediments offshore (Macdonald \& Yu in press). Our results showed that compared to offshore marine sites (Stns 65 and 49), the freshwater-influenced areas (Stns Z2 and 66) differed in prokaryotic community structure and had enhanced microbial production.

Cyanobacterial concentrations were generally low at the marine sites, but 1 order of magnitude higher in the river. Cyanobacteria, including picocyanobacteria, are known to be of widespread importance in polar freshwater environments, including northern rivers (Rae \& Vincent 1998), and are typically observed in low or negligible abundance in polar seas. This latter obser- vation has been attributed to the cold-tolerant but not psychrophilic growth characteristics of high-latitude cyanobacteria (Tang \& Vincent 1999) and their inability to keep pace with loss processes such as advection and grazing in cold oceans (Vincent et al. 2000). Although picocyanobacteria were a minor constituent of the offshore heterotrophic prokaryote communities, their concentrations were higher than at equivalent latitudes in Antarctica, perhaps reflecting their continuous input into the Arctic Ocean from freshwater sources.

The marked decrease in $\beta$-Proteobacteria from freshwater to saltwater is in agreement with the known distribution of these microorganisms in temperate estuaries (Bouvier \& del Giorgio 2002, del Giorgio \& Bouvier 2002, Castle \& Kirchman 2004). They are often the dominant fraction in freshwater lakes, whereas they are nearly absent in the marine environment (Methé et al. 1998, Glöckner et al. 1999) and have been considered as a tracer of terrigenous inputs in coastal studies (Hobbie 1988). Clone library analysis of $\beta$-Proteobacteria in a temperate latitude estuary showed that they were identical to clones from groundwater, freshwater sediments and soils (Crump et al. 2004). Strongly freshwater-influenced marine sites can have relatively large proportions of these taxa, e.g. 15 to $29 \%$ of total counts in the Baltic Sea (Glöckner et al. 1999), while they are often absent from pelagic marine systems, including sites in the Southern Ocean (Glöckner et al. 1999) and offshore Arctic Ocean (Bano \& Hollibaugh 2002). However, recent molecular studies have identified marine $\beta$-Proteobacteria, notably phylotypes of Nitrosomonas and Nitrosospira (Nold et al. 2000, Freitag \& Prosser 2004, Sekar et al. 2004) at polar ocean sites (Hollibaugh et al. 2002). $\beta$-Proteobacteria have been recorded in lake snow (Weiss et al. 1998) and in the freshwater melt pools on Arctic pack ice (Brinkmeyer et al. 2004). However, these inputs appeared to be negligible in our shelf transect, with only a $3 \%$ contribution of these taxa to total counts at Stn 49, near the pack ice.

The greater importance of $\alpha$-Proteobacteria in marine samples of this transect is consistent with the widespread occurrence of this group throughout the world's oceans. The SAR11 clade (Pelagibacter ubique) within this lineage accounts for a major fraction of all ribosomal RNA genes that have been identified in the sea (Rappé et al. 2002), and the related $\alpha$-Proteobacteria Roseobacter is also widely distributed (Giovannoni \& Rappé 2000). Freshwater members of this lineage have also been found in abundance in rivers, e.g. up to $45 \%$ of total DAPI counts in tributaries of the Hudson River (Kirchman et al. 2004). However, our CARD-FISH analyses showed that they were a negligible component of the Mackenzie River micro- 
biota ( $2 \%$ of DAPI counts) at the time of sampling. The subclass of the $\gamma$-Proteobacteria had a similar pattern as the $\alpha$-Proteobacteria, contributing $<2 \%$ of total prokaryotes at the river sites. The $\gamma$-Proteobacteria were well represented at coastal and marine stations $(\leq 10 \%)$, in contrast to the view that they are a minor component of the bacterioplankton (Glöckner et al. 1999, Bouvier \& del Giorgio 2002).

The relative abundance of the CFB cluster was lowest at the river stations (Fig. 3). This is consistent with their affinity for the marine environment, where they can occur as the most abundant group (Glöckner et al. 1999). In the cold Southern Ocean, CFB cells accounted for 20 and $40 \%$ of total DAPI counts at the Polar Front and in the Antarctic Circumpolar Current, respectively (Simon et al. 1999). However, at marine sites in the present study, CFB cells were generally much lower in abundance relative to $\alpha$-Proteobacteria. It also has been reported that CFB cells were found in higher proportions in the freshwater section (mean: 28 $\pm 9 \%$ of DAPI counts) and decreased towards the marine section to $14 \pm 4 \%$ in the Weser estuary, Germany (Selje \& Simon 2003). Although CFB are often associated with particle surfaces (Kirchman 2002), there was no correlation in the present study to SPM.

In contrast to the CFB cluster, archaeal abundance varied greatly across the Mackenzie River and Beaufort Sea shelf transect, and cells of this domain appeared to be more prevalent in the turbid waters found at river and coastal stations. Archaea ranged from $1.3 \%$ of the DAPI counts at the marine sites to $6.1 \%$ at coastal sites, within the range ( 0 to $9 \%$ of DAPI counts) reported by Bouvier \& del Giorgio (2003) in surface water of various coastal and oceanic regions. In high-latitude seas, Archaea have been reported in surface waters to account for 1 to $15 \%$ of total DAPI counts in the Southern Ocean (Massana et al. 1998, Murray et al. 1998, Church et al. 2003) and for 0.1 to $2.6 \%$ in the Northwest Passage (Canadian Arctic; Wells \& Deming 2003). The affinity of Archaea for particles suggested by the present results is consistent with observations in the Northwest Passage, where the highest percentages of Archaea (2.3 to $13 \%$ ) were found in particle-rich layers of the water column (Wells \& Deming 2003). Archaea have been detected in bulk suspended sediment samples from the North Sea (van der Maarel et al. 1998) and Black Sea (King et al. 1998), and in association with particles $(>3 \mu \mathrm{m})$ in the Columbia River estuary (Crump \& Baross 2000a). A complementary oligo-FISH analysis using 4 different archaeal probes (including Arch915) was undertaken in parallel with the present study, including the same sites across the Mackenzie shelf (Wells et al. 2006). This analysis gave slightly higher relative Archaea values (average of $7.5 \%$ of total DAPI counts) than the present study, but the spatial pattern was similar, and the values correlated strongly with our own $(r=0.85$, slope $=1.4)$. The 2 data sets using different FISH protocols converge on the conclusion that there is a highly significant relationship between Archaea and particles on the river-influenced coastal arctic shelf.

Our size-fractionation experiments showed that particle-based communities dominated the microbial production at turbid, freshwater-influenced sites, with $<35 \%$ of the leucine uptake activity attributable to free-living cells. Some filter clogging could have resulted in an underestimation of uptake rates by freeliving prokaryotes; however, the samples flowed rapidly through the $3 \mu \mathrm{m}$ filters under low pressure, suggesting that any such effects were minimal. A high proportion of bacterial production associated with particles has been recorded in several other river-influenced systems, including the estuarine turbidity zones of the St. Lawrence River (Vincent et al. 1996) and the Columbia River (Crump \& Baross 2000b). Archaea have been detected in marine arctic sediments (Ravenschlag et al. 2001), and therefore another potential source of these microorganisms to the water column would be the resuspension of bottom sediments caused by wind-induced mixing or by the coastal upwelling observed during the sampling period. Regardless of the origin of the Archaea on the Mackenzie shelf, our leucine uptake results suggest that particle-based microbial communities, including Archaea, have a controlling influence on heterotrophic activity in this coastal arctic ecosystem.

Large quantities of organic carbon are stored in the catchments drained by arctic rivers. Dixon et al. (1994) estimated that these stocks amount to $30-50 \%$ of the global total for soil organic carbon, equivalent to twice the carbon presently contained in the atmospheric $\mathrm{CO}_{2}$ reservoir. Increased temperatures, permafrost melting and the potential for increased runoff and mobilization of these northern carbon reserves highlight the need to better understand the heterotrophic potential for decomposing terrestrial carbon sources in the coastal Arctic Ocean. Our results show that this marine ecosystem has a number of distinctive features, such as particle-based heterotrophy, bacterial and archaeal inputs, and a diverse microbial flora. These features also imply a broad metabolic and functional diversity in this microbial system, with complementary enzymatic abilities that could aid the breakdown of dissolved and particulate terrestrial carbon discharged into arctic seas.

Acknowledgements. This study was made possible with financial support from the Natural Sciences and Engineering Research Council of Canada (NSERC), the Canada Research Chair program, Fonds québécois de recherche sur la nature et 
les technologies (FQRNT) and Indian and Northern Affairs Canada. We thank M. Fortier (Chief Scientist); L. Miller, M.-E. Rail and M. Robert (the rosette team); and the officers and crew of the CCGS 'Pierre Radisson' for their outstanding help during the expedition in the fall of 2002 in the Beaufort Sea. We are also grateful to C. Martineau for fieldwork and analysis; M. Carrière and A. Chapenoire for assistance with cell counts; L. Retamal for DOC data; K. Lacoste and S. Demers (ISMER) for chl a data at Stn Z5; M.-E. Rail for assistance with the hydrographic figure; and L. Wells and P. Galand for their valuable comments on the manuscript. This is a contribution to the Canada Arctic Shelf Exchange Study (CASES) under the overall direction of L. Fortier.

\section{LITERATURE CITED}

ACIA (Arctic Climate Impact Assessment) (2004) Impacts of a warming Arctic. Cambridge University Press, New York

Amann RI, Binder BJ, Olson RJ, Chisholm SW, Devereux R, Stahl DA (1990) Combination of 16S rRNA-targeted oligonucleotide probes with flow cytometry for analyzing mixed microbial populations. Appl Environ Ecol 56: 1919-1925

Amon RMW (2004) The role of dissolved organic matter for the organic carbon cycle in the Arctic Ocean. In: Stein R, Macdonald RW (eds) The organic carbon cycle in the Arctic Ocean. Springer-Verlag, Berlin, p 83-98

Bano N, Hollibaugh JT (2002) Phylogenetic composition of bacterioplankton assemblages from the Arctic Ocean. Appl Environ Ecol 68:505-518

Bano N, Ruffin S, Ransom B, Hollibaugh JT (2004) Phylogenetic composition of Arctic Ocean Archaeal assemblages and comparison with Antarctic assemblages. Appl Environ Ecol 70:781-789

Bouvier TC, del Giorgio PA (2002) Compositional changes in free-living bacterial communities along a salinity gradient in two temperate estuaries. Limnol Oceanogr 47:453-470

Bouvier TC, del Giorgio PA (2003) Factors influencing the detection of bacterial cells using fluorescence in situ hybridization (FISH): a quantitative review of published reports. FEMS Microbiol Ecol 44:3-15

Brinkmeyer R, Glöckner FO, Helmke E, Amann R (2004) Predominance of $\beta$-Proteobacteria in summer melt pools on Arctic pack ice. Limnol Oceanogr 49:1013-1021

Carmack EC, Macdonald RW (2002) Oceanography of the Canadian shelf of the Beaufort Sea: a setting for marine life. Arctic 55(Suppl 1):29-45

Carmack E, Macdonald R, Jasper S (2004) Phytoplankton productivity on the Canadian shelf of the Beaufort Sea. Mar Ecol Prog Ser 277:37-50

Castle D, Kirchman DL (2004) Composition of estuarine bacterial communities assessed by denaturing gradient gel electrophoresis and fluorescence in situ hybridization. Limnol Oceanogr Methods 2:303-314

Cauwet G, Sidorov I (1996) The biogeochemistry of Lena River: organic carbon and nutrients distribution. Mar Chem 53:211-227

Church MJ, DeLong EF, Ducklow HW, Karner MB, Preston CM, Karl DM (2003) Abundance and distribution of planktonic Archaea and Bacteria in the waters west of the Antarctic Peninsula. Limnol Oceanogr 48:1893-1902

Cottrell MT, Kirchman DL (2003) Contribution of major bacterial groups to bacterial biomass production (thymidine and leucine incorporation) in the Delaware estuary. Limnol Oceanogr 48:168-178

Crump BC, Baross JA (2000a) Archaeaplankton in the Colum- bia River, its estuary and the adjacent coastal ocean, USA. FEMS Microbiol Ecol 31:231-239

Crump BC, Baross JA (2000b) Characterization of the bacterially-active particle fraction in the Columbia River estuary. Mar Ecol Prog Ser 206:13-22

Crump BC, Hopkinson CS, Sogin ML, Hobbie JE (2004) Microbial biogeography along an estuarine salinity gradient: combined influences of bacterial growth and residence time. Appl Environ Ecol 70:1494-1505

Daims H, Bruhl A, Amann R, Schleifer KH, Wagner M (1999) The domain-specific probe EUB338 is insufficient for the detection of all Bacteria: development and evaluation of a more comprehensive probe set. Syst Appl Microbiol 22: 434-444

del Giorgio PA, Bouvier TC (2002) Linking the physiologic and phylogenetic successions in free-living bacterial communities along an estuarine salinity gradient. Limnol Oceanogr 47:471-486

Dickson D, Gilchrist H (2002) Status of marine birds of the southeastern Beaufort Sea. Arctic 55(Suppl 1):46-58

Dixon RK, Brown S, Houghton RA, Solomon AM, Trexler MC, Wisniewski J (1994) Carbon pools and flux of global forest ecosystems. Science 263:185-190

Droppo IG, Jeffries D, Jaskot C, Backus S (1998) The prevalence of freshwater flocculation in cold regions: a case study from the Mackenzie River Delta, Northwest Territories, Canada. Arctic 51:155-164

Environment Canada (2002) Archives nationales d'information et de données climatologiques. Available at: www. climat.meteo.ec.gc.ca/climateData/canada_f.html

Freitag TE, Prosser JI (2004) Differences between betaproteobacterial ammonia-oxidizing communities in marine sediments and those in overlying water. Appl Environ Microbiol 70:3789-3793

Giovannoni S, Rappé M (2000) Evolution, diversity and molecular ecology of marine prokaryotes. In: Kirchman DL (ed) Microbial ecology of the oceans. Wiley-Liss, New York, p 47-84

Glöckner FO, Fuchs BM, Amann R (1999) Bacterioplankton compositions of lakes and oceans: a first comparison based on fluorescence in situ hybridization. Appl Environ Ecol 65:3721-3726

Harwood L, Smith T (2002) Whales of the Inuvialuit settlement region in Canada's western Arctic: an overview and outlook. Arctic 55(Suppl 1):77-93

Herndl GJ, Reinthaler T, Teira E, van Aken H, Veth C, Pernthaler A, Pernthaler J (2005) Contribution of Archaea to total prokaryotic production in the deep Atlantic Ocean. Appl Environ Ecol 71:2303-2309

Hobbie JE (1988) A comparison of the ecology of planktonic bacteria in fresh and salt water. Limnol Oceanogr 33: $750-764$

Hollibaugh JT, Bano N, Ducklow HW (2002) Widespread distribution in polar oceans of a 16S rRNA gene sequence with affinity to Nitrosospira-like ammonia-oxidizing bacteria. Appl Environ Microbiol 68:1478-1484

Kaneko T, Atlas RM, Krichevsky M (1977) Diversity of bacterial populations in the Beaufort Sea. Nature 270:596-599

Kaneko T, Krichevsky MI, Atlas RM (1978a) Numerical taxonomy of bacteria from the Beaufort Sea. J Gen Microbiol 110:111-125

Kaneko T, Roubal G, Atlas RM (1978b) Bacterial populations in the Beaufort Sea. Arctic 31:97-107

King LL, Pease TK, Wakeham SG (1998) Archaea in Black Sea water column particulate matter and sediments-evidence from ether lipid derivatives. Org Geochem 28: $677-688$ 
Kirchman DL (2002) The ecology of Cytophaga-Flavobacteria in aquatic environments. FEMS Microbiol Ecol 39: 91-100

Kirchman DL, Ducklow HW (1993) Estimating conversion factors for the thymidine and leucine methods for measuring bacterial production. In: Kemp PF, Sherr BF, Sherr EB, Cole JJ (eds) Handbook of methods in aquatic microbial ecology. Lewis Publications, Boca Raton, FL, p 513-517

Kirchman DL, Dittel AI, Findlay SEG, Fischer D (2004) Changes in bacterial activity and community structure in response to dissolved organic matter in the Hudson River, New York. Aquat Microb Ecol 35:243-257

Knap A, Michaels A, Close A, Ducklow H, Dickson A (eds) (1996) Protocols for the Joint Global Ocean Flux Study (JGOFS) core measurements. JGOFS Report No. 19, Reprint of the IOC manuals and guides, No. 29, UNESCO, Paris

Lovejoy C, Legendre L, Martineau MJ, Bâcle J, von Quillfeldt CH (2002) Distribution of phytoplankton and other protists in the North Water. Deep-Sea Res II 49:5027-5047

Macdonald RW, Yu Y (in press) The Mackenzie Estuary of the Arctic Ocean. In: Wangersky PJ (ed) Water pollution: estuaries, Vol 5. Springer-Verlag, Heidelberg

Macdonald RW, Solomon SM, Cranston RE, Welch HE, Yunker MB, Gobeil C (1998) A sediment and organic carbon budget for the Canadian Beaufort shelf. Mar Geol 144:255-273

Manz W, Amann R, Ludwig W, Wagner M, Schleifer KH (1992) Phylogenetic oligodeoxynucleotide probes for the major subclasses of Proteobacteria: problems and solutions. Syst Appl Microbiol 15:593-600

Manz W, Amann R, Ludwig W, Vancanneyt M, Schleifer K (1996) Application of a suite of 16S rRNA-specific oligonucleotide probes designed to investigate bacteria of the phylum Cytophaga-Flavobacter-Bacteroides in the natural environment. Microbiology 142:1097-1106

Marcotte D (1991) Cokriging with MATLAB. Comput Geosci $17: 1265-1280$

Massana R, Taylor LT, Murray AE, Wu K, Jeffrey WH, DeLong EF (1998) Vertical distribution and temporal variation of marine planktonic Archaea in the Gerlache Strait, Antarctica, during early spring. Limnol Oceanogr 43: 607-617

Methé BA, Hiorns WD, Zehr JP (1998) Contrasts between marine and freshwater bacterial community composition: analyses of communities in Lake George and six other Adirondack lakes. Limnol Oceanogr 43:368-374

Mueller DR, Vincent WF, Jeffries MO (2003) Break-up of the largest Arctic ice shelf and associated loss of an epishelf lake. Geophys Res Lett 30: 2031. DOI 10.1029/2003 -GL017931

Murray AE, Preston CM, Massana R, Taylor LT, Blakis A, Wu K, DeLong EF (1998) Seasonal and spatial variability of bacterial and archaeal assemblages in the coastal waters near Anvers Island, Antarctica. Appl Environ Ecol 64: 2585-2595

Myers JL, Well AD (2003) Research design and statistical analysis. Lawrence Erlbaum Associates, London

Neef A (1997) Anwendung der in situ-Einzelzell-Identifizierung von Bakterien zur Populationsanalyse in komplexen mikrobiellen Biozönosen. Doctoral thesis, Technische Universität München, Munich

Nold SC, Zhou JZ, Devol AH, Tiedje JM (2000) Pacific Northwest marine sediments contain ammonia-oxidizing bacteria in the beta subdivision of the Proteobacteria. Appl Environ Microbiol 66:4532-4535

Nusch EA (1980) Comparison of different methods for chlorophyll and phaeopigment determination. Arch Hydrobiol
Beih 14:14-36

Ouverney CC, Fuhrman JA (2000) Marine planktonic Archaea take up amino acids. Appl Environ Microbiol 66:4829-4833

Payette S, Delwaide A, Caccianiga M, Beauchemin M (2004) Accelerated thawing of subarctic peatland permafrost over the last 50 years. Geophys Res Lett 31:L18208. DOI 10.1029/2004GL020358

Pernthaler A, Pernthaler J, Amann R (2002) Fluorescence in situ hybridization and catalyzed reporter deposition for the identification of marine bacteria. Appl Environ Ecol 68:3094-3101

Pernthaler J, Glöckner FO, Schönhuber W, Amann R (2001) Fluorescence in situ hybridization (FISH) with rRNA-targeted oligonucleotide probes. In: Paul JH (ed) Methods in microbiology. Academic Press, San Diego, CA, p 206-226

Peterson BJ, Holmes RM, McClelland JW, Vörösmarty CJ, Lammers RB, Shiklomanov AI, Shiklomanov IA, Rahmstorf S (2002) Increasing river discharge to the Arctic Ocean. Science 298:2171-2173

Rae R, Vincent WF (1998) Effects of temperature and ultraviolet radiation on microbial foodweb structure: potential responses to global change. Freshw Biol 40:747-758

Rappé MS, Connon SA, Vergin KL, Giovanni SJ (2002) Cultivation of the ubiquitous SAR11 marine bacterioplankton clade. Nature 418:630-633

Ravenschlag KK, Sahm K, Amann R (2001) Quantitative molecular analysis of the microbial community in marine Arctic sediments (Svalbard). Appl Environ Microbiol 67: 387-395

Schippers A, Neretin LN, Kallmeyer J, Ferdelman TG, Cragg BA, John Parkes R, Jørgensen BB (2005) Prokaryotic cells of the deep sub-seafloor biosphere identified as living bacteria. Nature 433:861-864

Sekar A, Fuchs BM, Amann R, Pernthaler J (2004) Flow sorting of marine bacterioplankton after fluorescence in situ hybridization. Appl Environ Microbiol 70:6210-6219

Sekar R, Pernthaler A, Pernthaler J, Warnecke F, Posch T, Amann R (2003) An improved protocol for quantification of freshwater Actinobacteria by fluorescence in situ hybridization. Appl Environ Microbiol 69:2928-2935

Selje N, Simon M (2003) Composition and dynamics of particle-associated and free-living bacterial communities in the Weser estuary, Germany. Aquat Microb Ecol 30:221-237

Serreze MC, Walsh JE, Chapin FS, Osterkamp T and 6 others (2000) Observational evidence of recent change in the northern high-latitude environment. Clim Change 46: 159-207

Simon M, Glöckner FO, Amann R (1999) Different community structure and temperature optima of heterotrophic picoplankton in various regions of the Southern Ocean. Aquat Microb Ecol 18:275-284

Stahl DA, Amann R (1991) Development and application of nucleic acid probes. In: Stackebrandt E, Goodfellow M (eds) Nucleic acid techniques in bacterial systematics. John Wiley \& Sons, Chichester, p 205-248

Stirling I (2002) Polar bears and seals in the eastern Beaufort Sea and Amundsen Gulf: a synthesis of population trends and ecological relationships over three decades. Arctic 55 (Suppl 1):59-76

Strickland JDH, Parsons TR (1972) A practical handbook of seawater analysis. Bull Fish Res Board Can 167:1-310

Stroeve JC, Serreze MC, Fetterer F, Arbetter T, Meier W, Maslanik J, Knowles K (2005) Tracking the Arctic's shrinking ice cover: another extreme September minimum in 2004. Geophys Res Lett 32:L04501. DOI 10.1029/2004 GL021810 
Tang EPY, Vincent WF (1999) Strategies of thermal adaptation by high-latitude cyanobacteria. New Phytol 142: 315-323

Telang SA, Pocklington R, Naidu AS, Romankevich EA, Gitelson II, Gladyshev MI (1991) Carbon and mineral transport in major North American, Russian Arctic, and Siberian rivers: the St. Lawrence, the Mackenzie, the Yukon, the Arctic Alaskan rivers, the Arctic Basin rivers in the Soviet Union, and the Yenisei. In: Degens ET, Kempe S, Richey JE (eds) SCOPE 42: biogeochemistry of major world rivers. John Wiley \& Sons, London, p 75-104

van der Maarel MJEC, Artz RRE, Haanstra R, Forney LJ (1998) Association of marine Archaea with the digestive tracts of two marine fish species. Appl Environ Microbiol 64:2894-2898

Vincent W, Dodson J, Bertrand N, Frenette JJ (1996) Photosynthetic and bacterial production gradients in a larval fish nursery: the St. Lawrence River transition zone. Mar Ecol Prog Ser 139:227-238

Vincent WF, Bowman J, Powell L, McMeekin T (2000) Phylogenetic diversity of picocyanobacteria in Arctic and Antarctic ecosystems. In: Brylinsky M, Bell C, JohnsonGreen P (eds) Microbial biosystems: new frontiers. Proceedings of the 8th international symposium on microbial ecology. Atlantic Canada Society for Microbial Ecology, Halifax, p 317-322

Editorial responsibility: Jed Fuhrman,

Los Angeles, California, USA
Wallner G, Amann R, Beisker W (1993) Optimizing fluorescent in situ hybridization with rRNA-targeted oligonucleotide probes for flow cytometric identification of microorganisms. Cytometry 14:136-143

Weiss P, Schweitzer B, Amann R, Simon M (1998) Identification in situ and dynamics of bacteria on limnetic organic aggregates (lake snow). Appl Environ Ecol 62: 998-2005

Wells LE, Deming JW (2003) Abundance of Bacteria, the Cytophaga-Flavobacterium cluster and Archaea in cold oligotrophic waters and nepheloid layers of the Northwest Passage, Canadian Archipelago. Aquat Microb Ecol 31: 19-31

Wells LE, Cordray M, Bowerman S, Miller LA, Vincent WF, Deming JW (2006) Archaea in particle-rich waters of the Beaufort Shelf and Franklin Bay, Canadian Arctic: clues to an allochthonous origin? Limnol Oceanogr 51:47-59

Williams PJleB (1985) Analysis: organic matter. In: Head PC (ed) Practical estuarine chemistry: a handbook. Cambridge University Press, Cambridge, p 160-200

Zar JH (1999) Biostatistical analysis. Prentice-Hall, Upper Saddle River, NJ

Zwart G, Crump BC, Kamst-van Agterveld MP, Hagen F, Han SK (2002) Typical freshwater bacteria: an analysis of available 16S rRNA gene sequences from plankton of lakes and rivers. Aquat Microb Ecol 28:141-155

Submitted: June 16, 2005; Accepted: September 26, 2005 Proofs received from author(s): December 28, 2005 